\title{
Promotion of Long Duration Rice Variety Swarna sub-1 through Frontline Demonstrations in Chandauli District of Uttar Pradesh, India
}

\author{
Samir Kumar Pandey ${ }^{1}$, Dheeraj Kumar Tiwari ${ }^{2 *}$, Sunil Singh ${ }^{2}$ and Prapti Singh ${ }^{3}$ \\ ${ }^{1}$ Krishi Vigyan Kendra, Chandauli-232104 (Uttar Pradesh), India \\ ${ }^{2}$ ICAR - Krishi Vigyan Kendra, Unnao - 229881 (Uttar Pradesh), India \\ ${ }^{3}$ Nandini Nagar Post Graduate College, Gonda - 271303 (Uttar Pradesh), India \\ *Corresponding author
}

\begin{abstract}
A B S T R A C T
Keywords

Extension gap,

Frontline demonstration, Line transplanting, Net returns, Paddy, Swarna sub-1

Article Info

Accepted:

20 April 2018

Available Online:

10 May 2018

Paddy is a predominant kharif crop of Uttar Pradesh as well as the country and plays a major role in augmenting the income of small and marginal farmers of Chandauli district of Uttar Pradesh. One of the major constraints of traditional paddy cultivation is low productivity due to non-adoption of recommended package of practices and improved varieties. To overcome this anomaly Krishi Vigyan Kendra, Chandauli conducted frontline demonstrations in farmers' fields at different locations in the district with high yielding variety Swarna sub-1 and applying scientific practices in cultivation including line transplanting. The paddy productivity and economic returns under improved technologies were calculated and compared with the prevailing farmers' practice. Results revealed that Swarna sub-1 variety under improved practices recorded higher yield of $15.51 \%$ and $18.55 \%$ during 2015-16 and 2016-17 and the recommended practice gave higher net returns of Rs 56856 and 60595 per ha and B:C ratio of 3.86:1 and 3.99:1 respectively as compared to farmers practice.
\end{abstract}

\section{Introduction}

Paddy crop holds the key for food security of Uttar Pradesh as well as the country. In Uttar Pradesh presently the crop is grown in 5.63 million hectare areas with a production of 11.94 million tones (Anon., 2014). Mostly the farmers of this region are going for cultivation of medium-long duration (140- 150 days) rice varieties as irrigated and rainfed crop. Swarna Sub-1, BPT -5204, Mashuri, Ranjit, etc are the popular rice varieties mostly grown in the low land area of the district; but among these
Swarna Sub-1 is the predominant variety rice growing low land area. Swarna Sub-1 has high production potential and also resistant to water logged condition. Apart from the improved agronomic practice unawareness of the farmers about the improved high yielding varieties and adoption of proper package of practices are also the reasons responsible for limiting the production and productivity of paddy.

Keeping this in view Krishi Vigyan Kendra, Chandauli (UP) had taken up demonstrations 
to introduce and popularize sowing of Swarna Sub-1 variety of paddy in the real farm situation.

\section{Materials and Methods}

Frontline demonstrations (FLDs) in Paddy were conducted during Kharif 2015 and 2016 by Krishi Vigyan Kendra, Chandauli at the farmers' fields in different locations of the district. A total of 75 demonstrations in 31 ha area were conducted in the selected villages. The improved variety Swarna Sub -1 was procured from N. D. University of Agriculture and Technology, Kumarganj Faizabad for demonstration purpose. In case of local check plots, existing practice of transplanting was followed by the farmers. The whole package approach demonstrated to farmers through FLD trials included components such as improved variety, line transplanting, recommended seed rate, seed treatment, weed and water management, fertilizers and plant protection measures (Table 1). In the demonstration plots critical inputs in the form of improved seed of Swarna Sub-1 variety and balanced fertilizers were provided to the farmers. Traditional practices were maintained in case of local checks. The farmers involved in demonstrations were facilitated by KVK scientists in performing proper field operations like timely sowing of nursery transplanting, spraying and harvesting. During this period extension activities like field days, farmers' trainings, diagnostic visits, etc. were undertaken which benefitted the farmers. Data on crop yield were recorded by per square meter observation method randomly from 3 to 4 places from an FLD plot. The yield data were collected from both the demonstrations and farmers' fields and analyzed using simple statistical tools. The technology gap, extension gap and technology index (Samui et al., 2000) were calculated using the following equation:

Technological gap: Potential yield demonstration yield
Extension gap: Demonstration yield - yield under farmer practice

Technology index (\%): (Potential yield demonstration yield/potential yield) X 100

\section{Results and Discussion}

The yield of paddy recorded under demonstration was 56.83 and 58.92 qha $^{-1}$ during kharif 2015 and 2016 respectively (Table 2). The yield enhancement due to the improved practices was to the tune of 15.51 and 18.55 per cent over farmers' practice. Yield enhancement in rice and other crops under frontline demonstration has amply been documented by Haque (2000) and Tiwari (2001). Extension gap of 7.63 and 9.22 q/ha was observed during kharif 2015 and 2016. Extension gap emphasized the need to bring awareness among the farmers for adoption of improved varieties and production technologies and to revert the trend of wide extension gap. Results also indicated technological gap between the improved technology and farmers' practice in tune of 10.17 and $8.08 \mathrm{qha}^{-1}$ during kharif 2015 and 2016 respectively. The technology gap observed may be attributed to difference in soil fertility status and agricultural practices and may be overcome by adopting efficient management practices. The technology index indicates the feasibility of the evolved technology at the farmers' fields. Lower the values of technology index more is the feasibility of the technology demonstrated (Chauhan, 2011). The technology index in the present study was 15.17 and 12.05 per cent showing the efficacy of good performance of technical interventions. The reduction in the technology index from 15.17 per cent in the first year to 12.05 per cent in the second year exhibited the feasibility of the technology demonstrated (Table 5). The data on economics of the improved technology indicate that the cost of production in FLD was higher than that of the local practice 
(Table 4). The input and output prices of the commodities prevailing during the study were taken into account for calculating the net returns and $\mathrm{B}: \mathrm{C}$ ratio. A higher net return of Rs 56856 and 60595 ha $^{-1}$ was recorded during both the years as compared to Rs 48175 and 53020 achieved as net returns in the farmers' practice. The benefit-cost ratio of paddy cultivation under improved cultivation practices was 3.86 and 3.99 during both the years as compared to 3.63 and 3.71 under farmers' practice. This may be due to higher yield obtained under improved technologies as compared to farmer's practice. The data on yield attributes of improved technology indicate that the no of matured panicles $\left(\mathrm{m}^{2}\right)$ and No of filled grains panicles ${ }^{-1}$ were 280295 and 170-195 recorded as compared to 210-220 and 130-135 under farmers practice. Moreover, the test weight (g) was 23.5-24 as compared to 22.5-23 under farmer practice (Table 3).

Table.1 Improved practices and Farmers practices of Paddy under FLD

\begin{tabular}{|c|c|c|c|c|}
\hline Sl. No. & Technology & $\begin{array}{l}\text { Improved practices } \\
\text { under flat sowing }\end{array}$ & Farmers practice & GAP (\%) \\
\hline 1 & Variety & Swarna Sub -1 & $\begin{array}{l}\text { BPT -5204, Mashuri, } \\
\text { Ranjit etc. }\end{array}$ & 100 \\
\hline 2 & Land preparation & $\begin{array}{l}\text { Ploughing, Harrowing } \\
\text { and pudling }\end{array}$ & $\begin{array}{l}\text { Ploughing, Harrowing } \\
\text { and pudling }\end{array}$ & 50 \\
\hline 3 & Seed rate & $12 \mathrm{~kg}(\mathrm{Ha})$ & $20 \mathrm{Kg}(\mathrm{Ha})$ & High seed rate \\
\hline 4 & Seed treatment & $\begin{array}{c}\text { Tricyclazole 75WP@2g } \\
\text { kg of seed }\end{array}$ & No application & 100 \\
\hline 5 & Sowing method & Line transplanting & Random transplanting & 100 \\
\hline 6 & $\begin{array}{l}\text { Herbicide } \\
\text { application }\end{array}$ & $\begin{array}{c}\text { Bispyribac-sodium 10\% } \\
\text { + clomazone 48\% @ } \\
0.25 \text { lit. per ha }\end{array}$ & $\begin{array}{c}\text { Butachlor @ } 2.0 \text { lit.per } \\
\text { ha }\end{array}$ & 100 \\
\hline 7 & Fertilizer dose & $\begin{array}{c}120-60-60(\mathrm{~N}-\mathrm{P}-\mathrm{K}) \text { and } \\
\mathrm{ZnSO}_{4} @ 25 \mathrm{~kg} \text { ha }\end{array}$ & $\begin{array}{l}\text { Indiscriminate } \\
\text { application }\end{array}$ & 50 \\
\hline 8 & Plant protection & IPM & $\begin{array}{l}\text { Indiscriminate } \\
\text { application }\end{array}$ & 100 \\
\hline
\end{tabular}

Table.2 Grain yield performances of Swarna sub-1 paddy variety under FLDs

\begin{tabular}{|c|c|c|c|c|c|}
\hline Year & $\begin{array}{c}\text { No. of } \\
\text { demonstrations }\end{array}$ & Area (ha) & $\begin{array}{c}\text { Demo } \\
\text { yield } \\
\left(\mathbf{q} \mathbf{h a}^{-\mathbf{1}}\right)\end{array}$ & $\begin{array}{c}\text { Farmers' } \\
\text { practice } \\
(\mathbf{c o n t r o l})(\mathbf{q} \\
\left.\mathbf{h a}^{-\mathbf{1}}\right)\end{array}$ & $\begin{array}{c}\text { Yield } \\
\text { increment } \\
(\mathbf{\%})\end{array}$ \\
\hline $\mathbf{2 0 1 5}$ & 33 & 13 & 56.83 & 49.20 & 15.51 \\
\hline $\mathbf{2 0 1 6}$ & 42 & 18 & 58.92 & 49.70 & 18.55 \\
\hline Mean & 37.5 & 15.5 & 57.87 & 49.45 & 17.03 \\
\hline
\end{tabular}


Table.3 Performances of yield attributes of paddy between FLD and farmers' practice

\begin{tabular}{|c|c|c|}
\hline Yield attributes & Demonstration & Farmers' practice \\
\hline No. of matured panicles $\mathrm{m}^{-2}$ & $280-295$ & $210-220$ \\
\hline No. of filled grains panicle ${ }^{-1}$ & $170-195$ & $130-135$ \\
\hline Test weight (g) & $23.5-24$ & $22.5-23$ \\
\hline
\end{tabular}

Table.4 Economical comparison of paddy cultivation between FLD and farmers' practice

\begin{tabular}{|c|c|c|c|c|c|c|c|c|}
\hline \multirow[b]{2}{*}{ Year } & \multicolumn{4}{|c|}{ Demonstration } & \multicolumn{4}{|c|}{ farmers' practice (control) } \\
\hline & $\begin{array}{l}\text { Cost of } \\
\text { cultivation } \\
\left(\text { Rs.ha }^{-1}\right)\end{array}$ & $\begin{array}{l}\text { Gross } \\
\text { return } \\
\left(\text { Rs.ha }^{-1}\right)\end{array}$ & $\begin{array}{l}\text { Net } \\
\text { return } \\
\left(\text { Rs.ha }^{-1}\right)\end{array}$ & B:C & $\begin{array}{c}\text { Cost of } \\
\text { cultivation } \\
\left(\text { Rs.ha }^{-1}\right)\end{array}$ & $\begin{array}{c}\text { Gross } \\
\text { return } \\
\left(\text { Rs.ha }^{-1}\right)\end{array}$ & $\begin{array}{l}\text { Net } \\
\text { return } \\
\left(\text { Rs.ha }^{-1}\right)\end{array}$ & B:C \\
\hline 2015 & 19865 & 76721 & 56856 & $3.86: 1$ & 18275 & 66420 & 48175 & $3.63: 1$ \\
\hline 2016 & 20255 & 80850 & 60595 & 3.99:1 & 19565 & 72585 & 53020 & $3.71: 1$ \\
\hline
\end{tabular}

Table.5 Impact of paddy var. Swarna sub-1 on technology gap, extension gap and technological index under FLDs

\begin{tabular}{|c|c|c|c|}
\hline Year & $\begin{array}{c}\text { Technology gap } \\
\left(\mathbf{q ~ h a} \mathbf{~ h a ~}^{-1}\right)\end{array}$ & $\begin{array}{c}\text { Extension gap } \\
\left(\mathbf{q} \mathbf{~ h a}^{-\mathbf{1}}\right)\end{array}$ & $\begin{array}{c}\text { Technology index } \\
(\mathbf{\%})\end{array}$ \\
\hline $\mathbf{2 0 1 5}$ & 10.17 & 7.63 & 15.17 \\
\hline $\mathbf{2 0 1 6}$ & 8.08 & 9.22 & 12.05 \\
\hline Mean & $\mathbf{8 . 1 2 5}$ & $\mathbf{8 . 4 2 5}$ & $\mathbf{1 3 . 6 1}$ \\
\hline
\end{tabular}

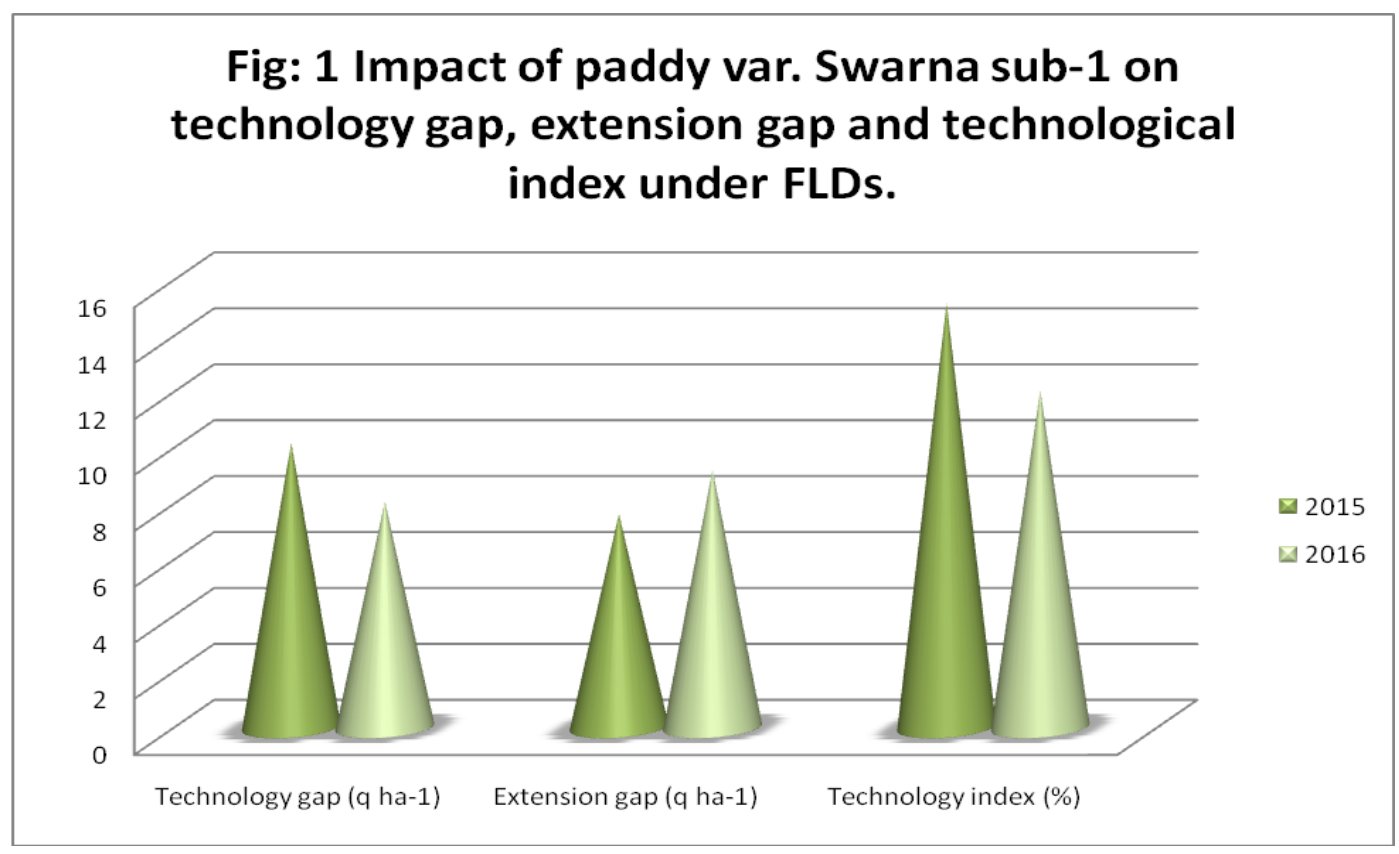

In conclusion, the yield potential of paddy conducting frontline demonstrations of the cultivation increased to a great extent by proven technology. This substantially 
increased the income as well as the livelihood of the farming community of the Chandauli district of Uttar Pradesh. Some of the factors constraining the full adoption of swarna sub-1 paddy variety. This variety of paddy (Swarna sub - 1) gained a momentum in upscaling the paddy productivity which created a positive impact on farming community.

\section{References}

Anonymous, 2014. Statistical Diary, Economics \& Statistics Division, State Planning Institute, U.P.

Anonymous, 2013. Agricultural Statistical at a Glance, Ministry of Agriculture, Govt. of India.

Chauhan, N.M. 2011. Impact and yield fissure inspection of gram through trainings and FLDs by KVK Tapi in Gujarat. Indian Journal of Agricultural Research and Extension, 4: 12-15.

Haque, M.S. 2000. Impact of compact block demonstration on increase in productivity of rice. Maharashtra Journal of Extension Education, 19 (1): 22-27.
Khanda, C. M., Mandal, B. K. and Garnayak, L. M. 2005. Effect of nutrient management on nutrient uptake and yield of component crops in rice-based cropping systems. Indian J. Agron., $50: 1-5$.

Mazumder, G., Das, J.K., Mazumdar, D. and Ghoshal, R. 2012. Assessment of yield in KVK programme: A multivariate approach. J. Crop Weed, 8:102-08.

Mukherjee, N. 2003. Participatory Learning and Action, Concept publishing company, New Delhi, India, pp. 63-65.

Prasad, C., Chaudhury, B. N. and Nayar, B. B. 1987. Rajasthan Agricultural Statistics at a Glance. ICAR, New Delhi, pp. 87.

Samui, S.K., Mitra, S., Roy, D.K., Mandal, A.K. and Saha, D. 2000. Evaluation of frontline demonstration on groundnut. Journal of the Indian Society of Coastal Agricultural Research, 18(2): 180-183.

Tiwari, K.B. and Saxena, A. 2001. Economic analysis of FLD of oilseeds in Chindwara. Bharatiya Krishi Anusandhan Patrika, 16 (3-4): 185-189.

\section{How to cite this article:}

Samir Kumar Pandey, Dheeraj Kumar Tiwari, Sunil Singh and Prapti Singh. 2018. Promotion of Long Duration Rice Variety Swarna sub-1 through Frontline Demonstrations in Chandauli District of Uttar Pradesh. Int.J.Curr.Microbiol.App.Sci. 7(05): 2870-2874. doi: https://doi.org/10.20546/ijcmas.2018.705.334 